\title{
AN ANALYSIS OF LOW CARBON ENERGY ASSESSORS (LCEA) IN PUBLIC BUILDINGS
}

DOI:10.36909/jer.ACMM.16327

\author{
K. Ayeratharasu Rajasekharan ${ }^{1}$, Porchelvan $\mathrm{P}^{1^{*}}$ \\ ${ }^{1}$ School of Civil Engineering, Vellore Institute of \\ Technology, Vellore, Tamil Nadu, India-632014 \\ Corresponding Author: porchelvanp467@gmail.com
}

\begin{abstract}
World has been shifting towards cleaner and safer sources of energy. Reducing the carbon footprint is the need of the hour. Industries all over the globe are researching on reducing the pollution causing emissions and trying to improve in terms of using sustainable sources of energy and saving the environment. This paper would analyse the low carbon energy assessors (LCEA) in the construction industry. A detailed study has been conducted using primary and secondary research to determine the carbon emissions at different stages of construction. The study would help us in identifying the main phases and activities and components, contributing the majority of the carbon footprints. The need of this age is to work on this area and minimise the pollution and harm to the environment. The construction sites chosen are diverse and consist of all types of building in the southern part of India. The highest carbon emission component in building construction is the cement as a large amount of $\mathrm{CO}_{2}$ emission takes place during the manufacturing process of the cement. The minimum carbon emission that takes place due to the components from the building are labour, sand, MS steel and stainless steel. The study would give a high level idea about the impact of low carbon energy assessors (LCEA) in the construction industry.
\end{abstract}

Keywords: Construction Industry, Energy Consumption, Carbon Footprint, LCEA, Carbon Emissions, Sustainability

\section{INTRODUCTION}

Industries all over the globe are contributing to the carbon footprint and adding to the disruption of nature's balance. Environment has been changing with the increasing emission of harmful gases which is mainly driven by the use of conventional sources of energy (Moncaster at el., 2019). Burning of these non-renewable sources of energy is not only 
depleting them from the earth, but also releasing the carbon and nitrogen compounds which are contributing to the ozone layer depletion and greenhouse effect. Global warming has been a critical issue recently and serious steps are being taken at international level to reduce the emission of harmful gases and reduce air pollution. This has paved the way for alternative and clean sources of energy and exploration of renewable sources of energy. Construction industry has been one of the major contributors in the list of carbon emitters. And this makes the study of this industry with respect to carbon emissions become inevitable (Mistretta at el., 2013 \& Gustavsson at el., 2010).

As per the studies conducted, construction sites generating carbon emissions are one of the major contributors of air pollution leading to the emission of greenhouse gases and global warming in the long run. It is not only impacting human health but also changing the global climate slowly (Nejat at el., 2015). Every year temperature has been increasing leading to a certain degree of increment in the environment temperature. Danger of melting ice caps and floods have been predicted by the scientists due to such alarming levels of air pollution which have been increasing every day. This generated an immense need to shift to cleaner sources of energy consumption (Goggins at el., 2016).

The alternatives have been explored in different areas and regulating the energy consumption pattern has been the most feasible option with a cleaner source of fuel. Technology is improving everyday and the energy sector has advanced accordingly to keep up with the changing pace (Kristjansdottir et al., 2018). Environmental concerns have increased over the past few decades and there has been a lot of hue and cry on shifting towards renewable and clean sources of energy. Overexploitation of energy being the major contributor of air pollution, there has been a continuous research going on to shift towards safer and less pollution causing alternatives. And to cater to this existing demand, efficient utilisation of energy programmes was launched all over the world which utilised sensors to power off the electrical utilities when not in use (C.S. et al., 2018. \& Stephan et al., 2012 ).

Construction Industry has brought technological innovations to minimise the emission of carbon and that has been possible with low carbon energy assessors (ICEA). It was a breakthrough in the energy sector, but it needed experience and technology to implement it on a large scale. And the cost of technology was huge. Apart from that, it needed a lot of time and effort to set up that infrastructure in all areas (Malmqvist et al., 2018). The task was huge and time taking. This generated a further scope of advancement which would solve this problem of dependency on the other methods of energy consumption pattern regulation. So, 
the engineers came up with the idea of using sensors to manage the energy consumption. This paper would talk about the feasibility of managing energy consumption in corporate, their impact on their CSR and the challenges faced by the energy sector to deal with this objective (Wiberg et al., 2018 \& Paulsen et al., 2018).

The different phases in the construction have different levels of carbon emissions and that can be studied to determine the high areas which could be worked upon to minimise the harmful emissions. The private sector companies focus on their growth and expansion to achieve maximum profit in the long run. However, the concept of sustainable development has always been a matter of debate, especially in developing nations like the World (Zhan et al., 2013). The paper has analysed the Social responsibility accounting in the qualified industrial zones of World using descriptive data analysis. The paper also focuses on the government legislation to support the social responsibility activities, in turn motivating the companies to work in this direction. The companies have been recommended to train the workers and make them skilled which would help them in creating a better job profile for themselves. The cost incurred in such activity has suggested to be given more weight to inculcate this feeling of working for the all round development of the nation. The paper has made certain recommendations regarding enforcing social accounting and use of qualified industrial zones for social responsibility accounting application rebates ( Iyer-Raniga et al., 2012 \& Cabeza et al., 2014).

A detailed research was done on the low carbon energy assessors in the construction industry. The research was conducted in two phases. First was the primary research with a survey questionnaire to understand the awareness about different construction phases and energy consumption and carbon emissions at each stage (Chau et al., 2015). The workers and companies were interviewed to understand the importance of social responsibility and know the challenges related to complying with the social responsibility norms. Further, a secondary research was conducted from the information available on the web to understand what companies think about social responsibility and their interest in adopting that. The research also focused on the drawbacks and the gaps in this area which could be filled to encourage the companies in complying with the social responsibility for a sustainable development of the nation (Dixi et al., 2010 Karimpour et al., 2014).

Social responsibility accounting by minimising the carbon emissions is a win-win situation for both the government and the companies. The companies providing community service 
and working in the direction of social development for saving the environment are in a way taking the burden of the states to work for saving mother earth or for a safer environment or for an inclusive growth and development (Cabeza et al., 2014). The nations would develop and in turn it would benefit the government in the long run. For the companies, it would be beneficial as they will get rebates under social responsibility accounting which would reduce their overall cost incurred and would also bring them a good social status. The brand image of the company would be built and would attract more investors which will help the company in further growth and expansion. The shareholders interest would also be served and that would bring more stability to the company (Khasreen et al., 2009 \& Svajlenka et al., 2018).

Low carbon energy assessors help in determining the efficient steps in the construction phase and participate in reducing the carbon footprint. Efficient utilisation of energy by regulating its consumption pattern has turned out to be an important and integral part of any organisation in the last few years (Singh et al., 2010). A lot of literature is available on the drivers behind the start and prevalence of this activity all over the world. The most important reason which has been found is the intrinsic motivation of the stakeholders working in the organisation. Usually, managers are supposed to work for the benefit of shareholders of the company and CSR is on the contrary for the benefit of non-shareholders ( Ramesh et al., 2010 \& Fay et al., 2000).

Studying at different construction sites and knowing different phases of the construction world help in a detailed understanding of the carbon emission at each stage. So ideally it should conflict the interests of shareholders. But, this is not the case in general as CSR activity increases the brand value of the company in the long run making the organisation more profitable and then serving the interests of shareholders eventually (Omrany et al., 2019 \& Ghaffarianhoseini et al., 2018). The reputation of any company would become better with the inclusion of CSR activity and investors would be attracted and motivated to invest in such a company and brand value comes with people's trust in the company. Companies doing work for the interest of society would gain that trust in the long run. The paper would summarize the effort taken by the companies to cut down their energy consumption by utilising the technology and adding to their CSR (Clements-Croome et al., 2018 \& Aye et al., 2012). 


\section{METHODOLOGY \\ PROJECT METHODOLOGY}

The world is moving towards sustainable ways of living and reducing the carbon footprints is one of those ways of contributing to a sustainable environment. The project would be testing the low carbon energy assessors to understand the carbon emission at the construction sites. The methodology involves assessing different construction sites including schools, guest houses, hostels, complexes, museums, offices, universities, quarters, government buildings etc. The study has been conducted on two sets of data assessing different construction sites. The project includes a detailed analysis of the different phases of the construction and the carbon emission at each of the construction phases (Ramesh et al., 2012 \& Ramesh et al., 2012).

\section{DESIGN FRAMEWORK}

The project design involves a step by step analysis of data for determining the low carbon energy assessors shown in figure 1. The project has been designed to understand the contribution of each stage of construction in the carbon footprint generation. Two sets of data have been prepared on different regions selected for case study (Bastos et al., 2014). Different types of buildings have been selected in the small districts of southern part of India. Different stages of construction have been analyzed for their individual contribution in the generation of carbon footprints. The different stages analyzed here are: Preliminary works, Structural works, Masonry works, Flooring works, Finishing works, Plumbing and sanitary works and then joineries shown in figure 2. The in depth study of all the stages of construction is to help us understand the scope of optimizing the Low Carbon Energy Assessors (LCEA) in the construction industry shown in figure 3 (Praseeda et al., 2016 \& Mehta et al., 2017). 


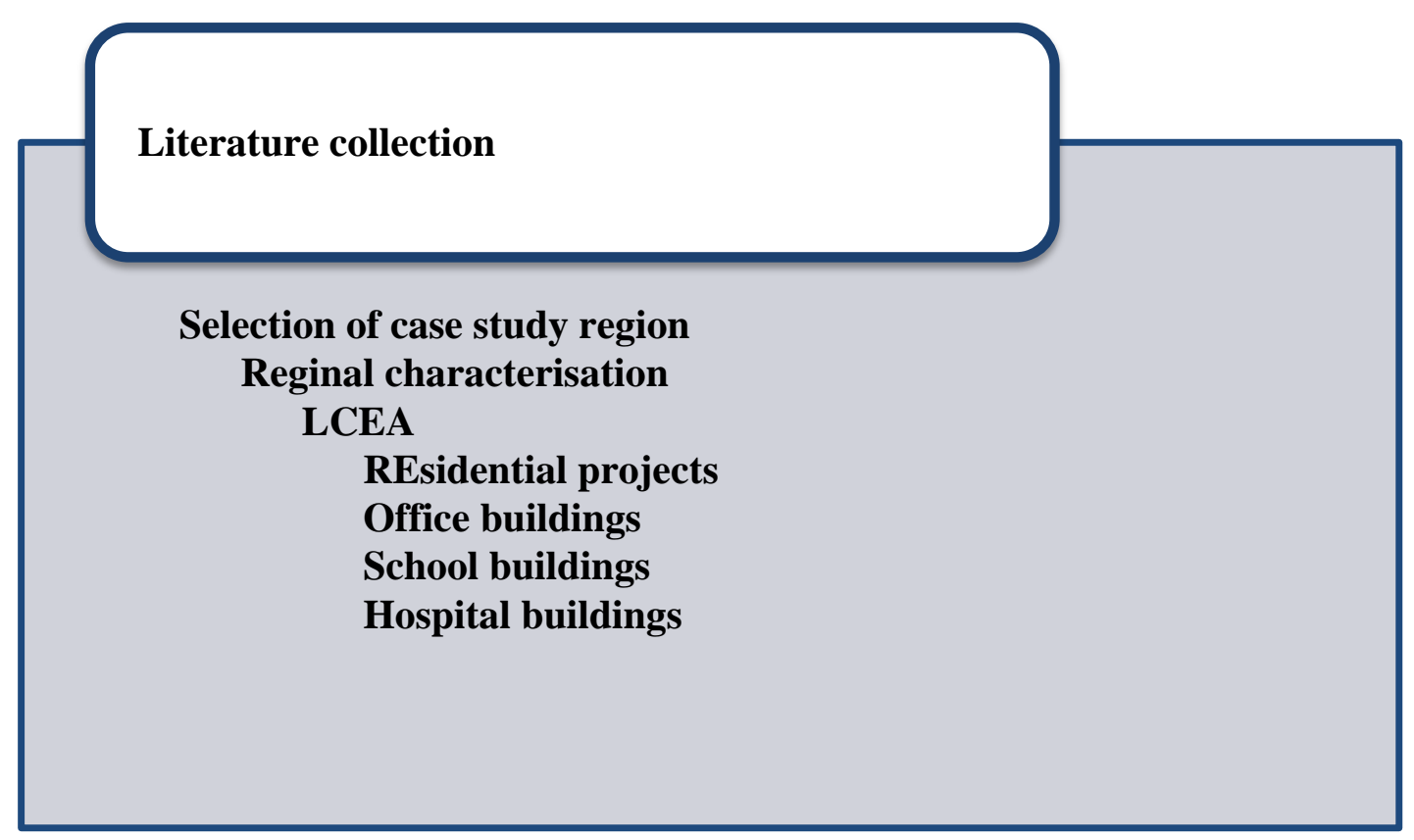

Figure 1 Design Framework of different stages of Buildings.

\begin{tabular}{lll}
\hline $\begin{array}{l}\text { Production } \\
\text { stage }\end{array}$ & Initial embodied energy (IEE) & Raw material production \\
& & Transportation \\
\cline { 2 - 3 } & & Production \\
\hline $\begin{array}{l}\text { Construction } \\
\text { stage }\end{array}$ & Embodied energy (EE) & Structural works \\
& & Masonry works \\
& & Finishing works \\
\hline $\begin{array}{l}\text { Service life } \\
\text { stage }\end{array}$ & Operational energy (OE) & MEP and other works \\
& & Lighting \\
\hline & & Space cooling \\
\hline $\begin{array}{l}\text { End of life } \\
\text { stage }\end{array}$ & Demolition energy (DE) & Ventilation \\
\hline
\end{tabular}

Figure 2 Different stages of the construction and the carbon emission 


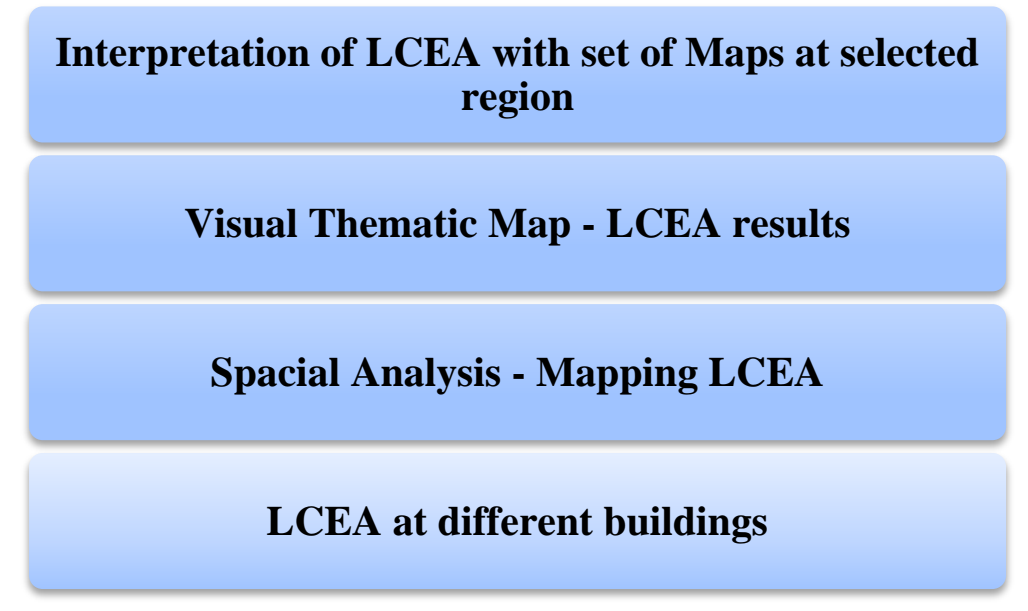

Figure 3 Design Framework

Further, the contribution of each factor involved in the construction was analyzed to understand their individual marks in generating the carbon footprint. The different factors considered in this study: Machine, Labour, Cement, Sand, Aggregate, Plastisizer, MS steel, TMT bars, Flyash bricks, Clay bricks, Kota stone, Ceramic floor, Vitrified tile, Granite, Marble, Teracotta, Anti skid concrete tile, Pressed clay tile, Solar reflective tile, Lime, Brick Jelly, Cement paint, Cement Primer, Acrylic Distemper, Acrylic Primer, Emulsion, Red oxide, Enamel, Enamel Putty, G.I Gypsum, Porcelien, PVC, G.I. UPVC, Glass, M.S Aluminium, UPVC, Wood, Glass PVC and Stainless Steel (Crawford et al., 2014 \& Devi et al., 2014 \& Gustavsson et al., 2010).

\section{RESULT AND DISCUSSION}

\section{EMISSION ANALYSIS FOR DIFFERENT CATEGORIES OF BUILDINGS}

The different category of building involves assessing different construction sites including schools, guest houses, hostels, complexes, museums, offices, universities, quarters, government buildings etc.

Two sets of primary data collected were analysed for the contribution of carbon emissions. Different categories of buildings were analysed and compared to determine the category of buildings emitting the higher amount of carbon energy in table 1,2 \& figure 4,5. 
Table 1 Different category of buildings set-1

\begin{tabular}{|c|l|l|l|l|l|}
\hline S.No & Category of Buildings & $\begin{array}{l}\text { Carbon } \\
\text { Emission } \\
\text { Quantity }(\mathbf{K g})\end{array}$ & $\begin{array}{l}\text { S.No } \\
\cdot\end{array}$ & $\begin{array}{l}\text { Category of } \\
\text { Buildings }\end{array}$ & $\begin{array}{l}\text { Carbon } \\
\text { Emission } \\
\text { Quantity } \\
\text { (Kg) }\end{array}$ \\
\hline 1 & School & 20000 & 19 & $\begin{array}{l}\text { Training } \\
\text { Institute }\end{array}$ & 3225 \\
\hline 2 & Maaligai & 10000 & 20 & University & 45000 \\
\hline 3 & School & 4500 & 21 & Quarters & 2189 \\
\hline 4 & Repair Work & 8545 & 22 & School & 2190 \\
\hline 5 & Guest House & 6340 & 23 & Repair Work & 3191 \\
\hline 6 & Mahal & 3452 & 24 & School & 5192 \\
\hline 7 & Sewage treatment plant & 2453 & 25 & School & 4193 \\
\hline 8 & Training Institute & 1454 & 26 & School & 2294 \\
\hline 9 & Repair Work & 3445 & 27 & School & 2225 \\
\hline 10 & School & 4456 & 28 & School & 2446 \\
\hline 11 & School & 2457 & 29 & School & 6197 \\
\hline 12 & School & 3400 & 30 & School & 898 \\
\hline 13 & School & 5459 & 31 & School & 1299 \\
\hline 14 & School & 3466 & 32 & Complex & 6930 \\
\hline 15 & School & 3444 & 33 & Musem & 2201 \\
\hline 16 & School & 3112 & 34 & Complex & 2346 \\
\hline 17 & School & 3003 & 35 & Office & 9892 \\
\hline 18 & Hostel (Clg) & 3464 & & & \\
\hline & & & & & \\
\hline
\end{tabular}

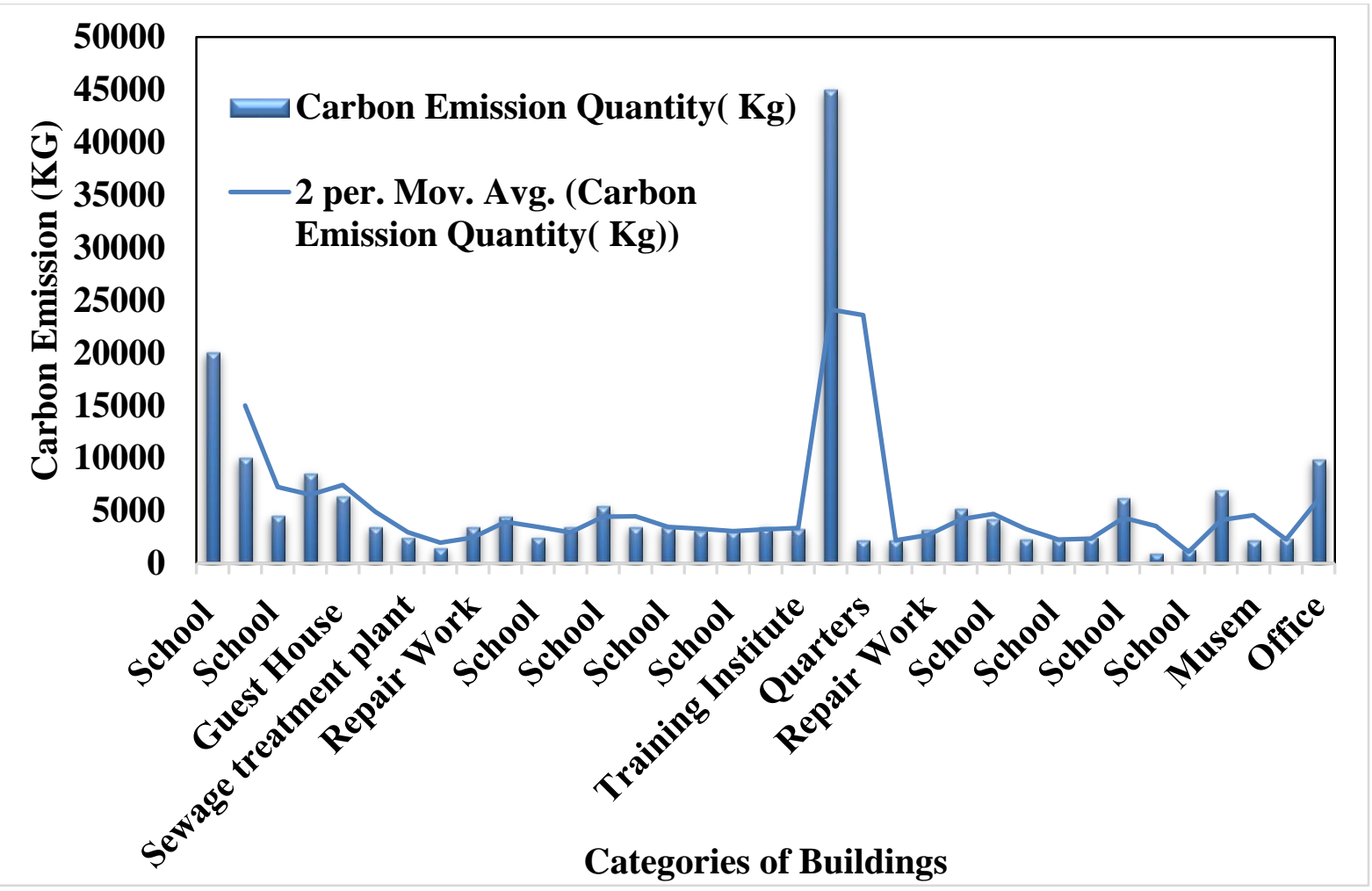


Figure 4 Carbon emissions for different categories of building -set 1

Table 2 Different category of buildings set-2

\begin{tabular}{|c|c|c|c|c|c|}
\hline $\begin{array}{l}\text { S.No } \\
\text {. } \\
\end{array}$ & $\begin{array}{l}\text { Category of } \\
\text { Buildings }\end{array}$ & $\begin{array}{l}\text { Carbon Emission } \\
\text { Quantity ( Kg) }\end{array}$ & S.No. & $\begin{array}{l}\text { Category of } \\
\text { Buildings }\end{array}$ & $\begin{array}{l}\text { Carbon Emission } \\
\text { Quantity ( Kg) }\end{array}$ \\
\hline 1 & School & 1239 & 18 & Hostel (Clg) & 1256 \\
\hline 2 & Maaligai & 1240 & 19 & Training Institute & 1257 \\
\hline 3 & School & 1321 & 21 & Quarters & 1258 \\
\hline 4 & Repair Work & 1674 & 22 & School & 1897 \\
\hline 5 & Guest House & 1783 & 23 & Repair Work & 1800 \\
\hline 6 & Mahal & 1944 & 24 & School & 1261 \\
\hline 7 & $\begin{array}{l}\text { Sewage } \\
\text { treatment plant }\end{array}$ & 10540 & 25 & School & 1462 \\
\hline 8 & $\begin{array}{l}\text { Training } \\
\text { Institute }\end{array}$ & 1446 & 26 & School & 1333 \\
\hline 9 & Repair Work & 1247 & 27 & School & 1264 \\
\hline 10 & School & 1148 & 28 & School & 1876 \\
\hline 11 & School & 1749 & 29 & School & 5489 \\
\hline 12 & School & 1650 & 30 & School & 1267 \\
\hline 13 & School & 11435 & 31 & School & 1568 \\
\hline 14 & School & 1252 & 32 & Complex & 1269 \\
\hline 15 & School & 1253 & 33 & Musem & 1470 \\
\hline 16 & School & 1254 & 34 & Complex & 4391 \\
\hline 17 & School & 1255 & 35 & Office & 1272 \\
\hline 18 & Hostel (Clg) & 1256 & & & \\
\hline
\end{tabular}




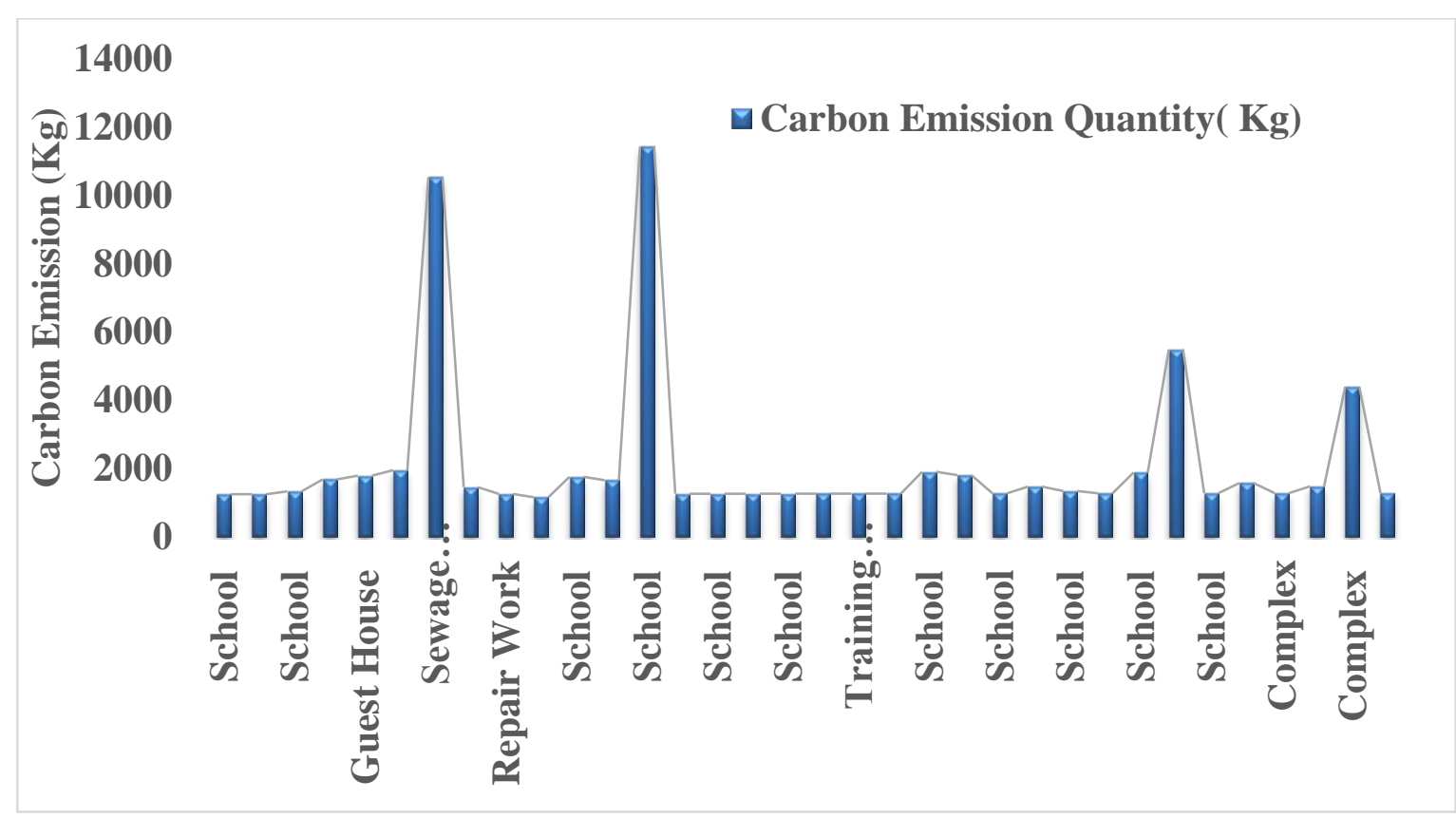

Figure 5 Carbon emissions for different categories of building -set 2

From both the charts, it is evident that universities, complexes both commercial and residential are the highest contributors of carbon emissions. Further, the data was analysed for each step of the construction phase to find out which stage is contributing the higher carbon emissions. In both the sets, it was consistent and was found that masonry contributed to the highest carbon footprint. In one of the sets, this was followed by the finishing work (Dodoo et al., 2014).

\section{EMISSION ANALYSIS FOR DIFFERENT STAGES OF CONSTRUCTION}

The entire construction process is divided into different stages. And each stage has its own sub process which leads to a unique level of requirements including carbon emissions. The different stages of construction were studied to analyse the carbon emissions at each stage of the process to determine the stages contributing to the highest emissions in figure 6,7. 


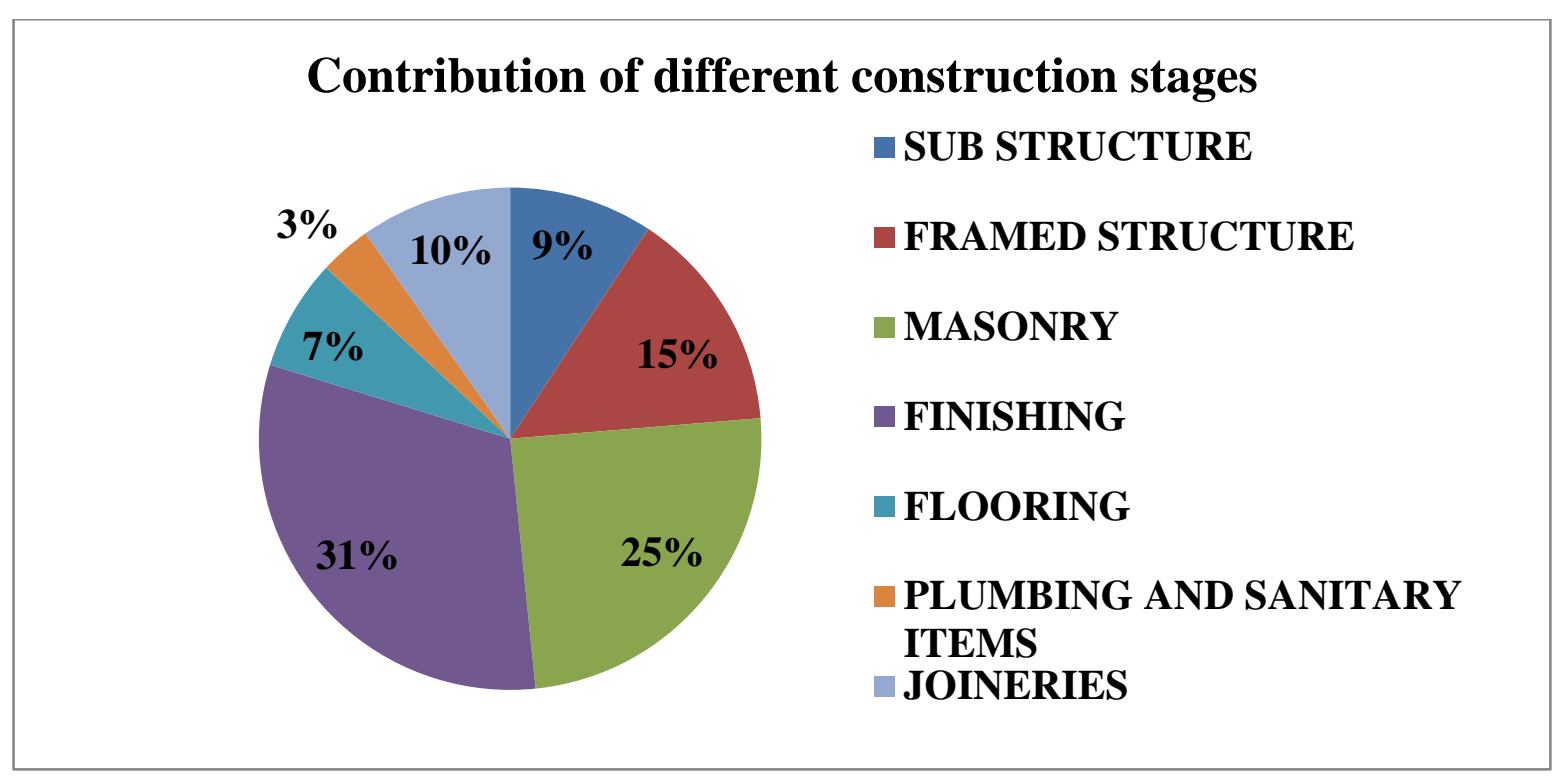

Figure 6 Carbon emissions for different stages of construction -set 1

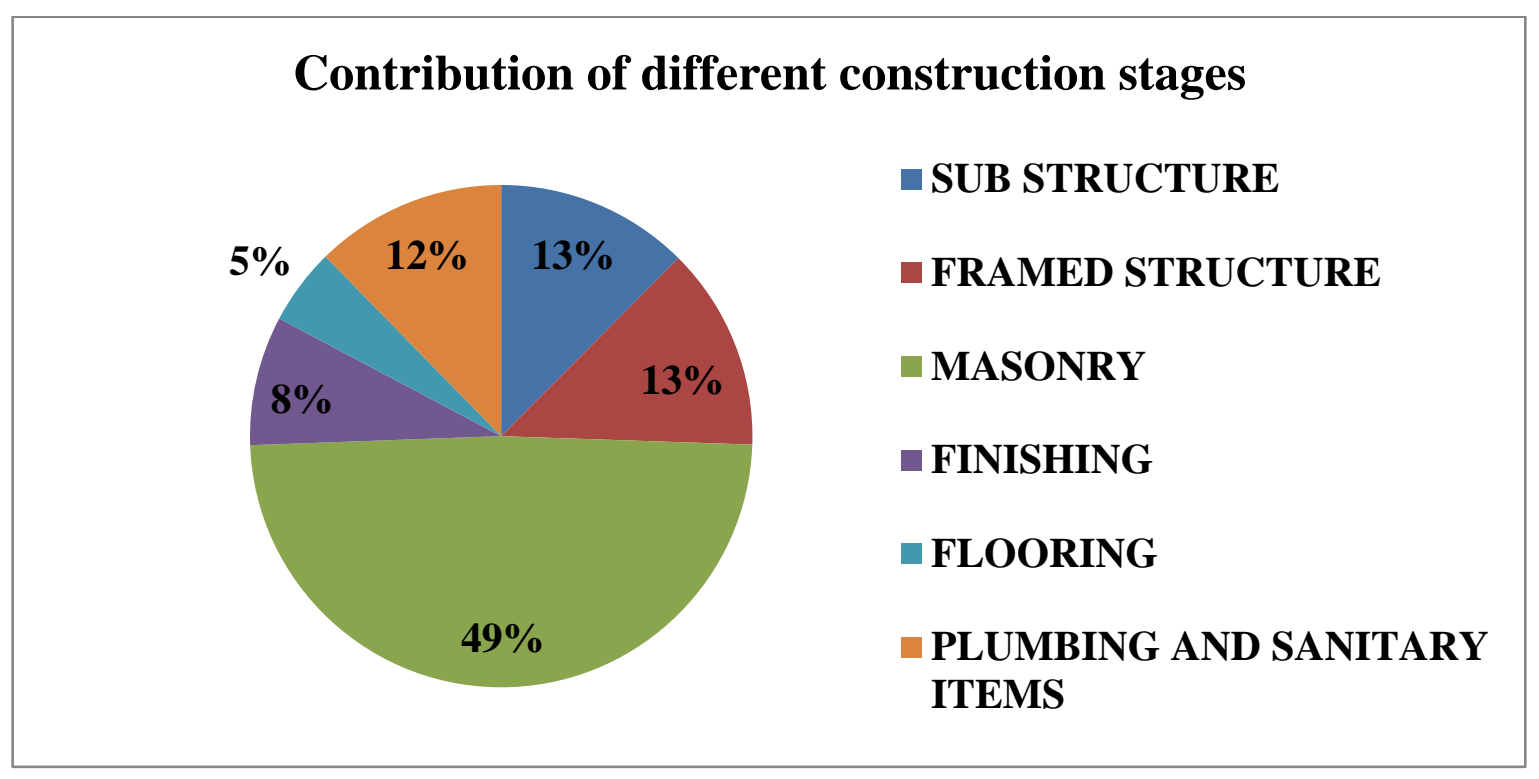

Figure 7 Carbon emissions for different stages of construction -set 2

The data analysed clearly stated that the initial stages of the construction like sub structure, framed structure along with the plumbing and flooring does not contribute much to the carbon emissions. Different sets of data and different categories of building confirmed this result. This could help in identifying the problem area to be worked Tettey et al., $2019 \&$ Zhu et al., 2018).

The different categories of building contributing to the higher carbon emissions could be chosen as the area of study to improve its impact on the environment sustainability. This result could be used to further study the scope of improvement for the impact of low carbon 
energy assessors (ICEA) on the environmental sustainability across the world (Dodoo et al., 2013).

\section{EMISSION ANALYSIS FOR DIFFERENT COMPONENTS OF CONSTRUCTION}

Like different stages of construction, there are different levels of carbon emissions in table 3 $\&$ figure 8. Similarly, different components release different levels of carbon. It can be seen from Figure 6 that cement is the highest contributor of carbon emission followed by bricks and machines. Cement contributes to around 4300 cum per day, bricks contribute to around 2000 cum per day and machine contributes to around 700 cum per day of emissions.

Table 3 Different stages of construction

\begin{tabular}{|c|c|c|}
\hline S.No. & Construction Components & Carbon emission \\
\hline 1 & Machine & 753 \\
\hline 2 & Labour & 0 \\
\hline 3 & cement & 4325 \\
\hline 4 & Sand & 0 \\
\hline 5 & aggregate & 330 \\
\hline 6 & Plasticizer & 0 \\
\hline 7 & MS steel & 200 \\
\hline 8 & TMT bars & 1800 \\
\hline 9 & Stainless steel & 0 \\
\hline 10 & Bricks & \\
\hline
\end{tabular}




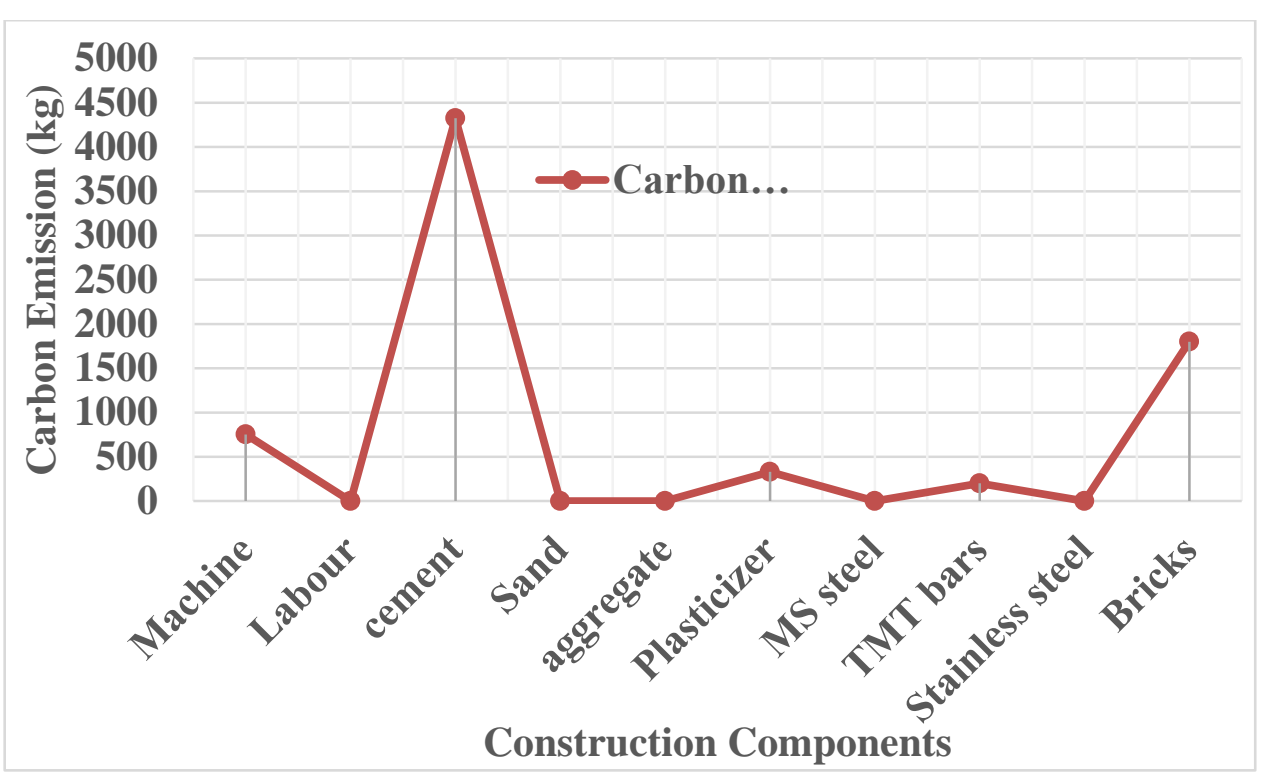

Figure 8 Carbon emissions for different components of construction

The highest carbon emission components in building construction is the cement as a large amount of $\mathrm{CO}_{2}$ emission takes place during the manufacturing process of the cement. The minimum carbon emission that takes place due to the components from the building are labour, sand, MS steel and stainless steel.

\section{CONCLUSION}

The construction industry is one of the major concern areas for the reduction of carbon footprints reduction. The industry emits carbon all around the year and has been a topic of study amongst the researchers worldwide. The Paper has successfully identified the category of buildings and construction stages contributing to the higher carbon emissions. The paper concludes that:

1) Universities and complexes (both commercial and residential) contributed to the highest carbon emissions.

2) Masonry contributed to $25 \%$ and $49 \%$ of the total emissions when analysed for the different stages of construction, for the 2 sets of data.

3) Finishing was another important construction stage contributing to $31 \%$ of the total emissions in stage 1.

4) Flooring stage is contributing the least to the emissions, being $7 \%$ and $5 \%$ for the 2 sets selected for the analysis. 
5) Cement contributes to the highest emissions of around 4300 cum per day followed by bricks which is 2500 cum per day and then machine which is 700 cum per day of emissions.

6) Overall, the construction industry has a huge scope of work and improvement for environment sustainability.

The next stage would be to focus on the categories of buildings and the stages of construction identified in this paper and research further to minimise their carbon emissions.

\section{REFERENCES}

Moncaster, A.M.; Rasmussen, F.N.; Malmqvist, T. 2019. Wiberg, A.H.; Birgisdottir, H. Widening understanding of low embodied impact buildings: Results and recommendations from 80 multinational quantitative and qualitative case studies. J. Clean. Prod. 235, 378393.

Mistretta, M.; Arcoleo, M.; Cellura, M.; Cesarini, D.N.; Guarino, F.; Longo, S. 2013. Refurbishment scenario to shift nearly net ZEBs toward net ZEB target: An Italian case study. In Nearly Zero Energy Building Refurbishment; Springer: London, UK, pp. 233-252.

Gustavsson, L.; Joelsson, A. 2010. Life cycle primary energy analysis of residential buildings. Energy Build. 42, 210-220.

Nejat, P.; Jomehzadeh, F.; Taheri, M.M.; Gohari, M.; Majid, M.Z.A. 2015. A global review of energy consumption, $\mathrm{CO}_{2}$ emissions and policy in the residential sector (with an overview of the top ten $\mathrm{CO}_{2}$ emitting countries). Renew. Sustain. Energy Rev. 43, 843-862.

Goggins, J.; Moran, P.; Armstrong, A.; Hajdukiewicz, M. 2016. Lifecycle environmental and economic performance of nearly zero energy buildings (NZEB) in Ireland. Energy Build. 116, 622-637.

Kristjansdottir, T.F.; Houlihan-Wiberg, A.; Andresen, I.; Georges, L.; Heeren, N.; Good, C.S.; Brattebø, H. 2018. Is a net life cycle balance for energy and materials achievable for a zero emission single-family building in Norway? Energy Build. 168, 457469.

Stephan, A.; Crawford, R.H.; De Myttenaere, K. 2012. Towards a comprehensive life cycle energy analysis framework for residential buildings. Energy Build. 55, 592-600.

Malmqvist, T.; Nehasilova, M.; Moncaster, A.; Birgisdottir, H.; Rasmussen, F.N.; Wiberg, A.H.; Potting, J. 2018. Design and construction strategies for reducing embodied impacts from buildings - Case study analysis. Energy Build. 166, 35-47. 
Paulsen, J.S.; Sposto, R.M. 2018. A life cycle energy analysis of social housing in Brazil: Case study for the program "MY HOUSE MY LIFE".

. Zhan, J.; Liu, W.; Wu, F.; Li, Z.; Wang, C. 2013. Life cycle energy consumption and greenhouse gas emissions of urban residential buildings in Guangzhou city. J. Clean. Prod. 194, 318-326.

Iyer-Raniga, U.; Wong, J.P.C. 2012. Evaluation of whole life-cycle assessment for heritage buildings in Australia. Build. Environ. 47, 138-149.

Cabeza, L.F.; Rincón, L.; Vilariño, V.; Pérez, G.; Castell, A. 2014. Life cycle assessment (LCA) and life cycle energy analysis (LCEA) of buildings and the building sector: A review. Renew. Sustain. Energy Rev. 29, 394-416.

Chau, C.K.; Leung, T.M.; Ng, W.Y. 2015. A review on life-cycle assessment, life-cycle energy assessment and life-cycle carbon emissions assessment on buildings. Appl. Energy , 143, 395-413.

Dixit, M.K.; Fernández-Solís, J.L.; Lavy, S.; Culp, C.H. 2010. Identification of parameters for embodied energy measurement: A literature review. Energy Build. 42, 1238-1247.

Karimpour, M.; Belusko, M.; Xing, K.; Bruno, F. 2014.Minimizing the life-cycle energy of buildings: Review and analysis. Build. Environ. 73, 106-11.

Cabeza, L.F.; Rincón, L.; Vilariño, V.; Pérez, G.; Castell, A. 2014. Life cycle assessment (LCA) and life cycle energy analysis (LCEA) of buildings and the building sector: A review. Renew. Sustain. Energy Rev. 29, 394-416.

Khasreen, M.; Banfill, P.F.; Menzies, G. 2009. Life-cycle assessment and the environmental impact of buildings: 